\title{
Maria Halamska
}

\section{Wspierać czy zalesiać? Dylematy rozwoju wiejskich obszarów problemowych}

Streszczenie: Około jednej trzeciej obszarów wiejskich w Polsce planiści zaliczyli do obszarów problemowych. Są to na ogół obszary peryferyjne i zmarginalizowane, charakteryzowane przez szereg deficytów (kapitału fizycznego, ludzkiego, społecznego i kulturowego), które nie mogą się rozwijać bez pomocy z zewnątrz i mają problemy nawet ze sformułowaniem celów rozwojowych. Wyzwania stawiane przez nowy paradygmat: sustainable rural development, odwołujący się do wielu elementów socjologicznej koncepcji rozwoju neoendogennego, są szczególnie istotne. Autorka, charakteryzując deficyty obszarów problemowych, podkreśla znaczenie deficytów ludzkich, społecznych i kulturowych. Taki jest kontekst zagadnienia zewnętrznej pomocy dla tych obszarów: jej charakteru oraz granic społecznej racjonalności. Koncepcja spirali negatywnego rozwoju Gerlind Weber i proponowany przez nią nowy paradygmat rozwoju dla części tych obszarów (paradygmat dopasowania) są użyteczne w wyjaśnianiu opisywanych zjawisk.

Słowa kluczowe: obszary problemowe, deficyty kapitałów, spirala negatywnego rozwoju, paradygmat dopasowania.

W ostatnim ćwierćwieczu polska wieś jest terenem wielorakich zmian. Jedną z nich - obserwowaną od przełomu wieków - jest bezwzględny i względny wzrost udziału ludności wiejskiej i odwrócenie tendencji migracyjnych miasto-wieś. Niektórzy skłonni byli (i są nadal) w tym zjawisku widzieć renesans wsi: lepiej infrastrukturalnie wyposażonej, zamożniejszej, dowartościowanej za ciszę, kontakt z przyrodą, jakość życia społecznego opartego na bezpośrednich, face to face, relacjach społecznych. Tymczasem obraz ten jest bardzo złożony, a zmiany na obszarach wiejskich zachodzą nierównomiernie. Obok obszarów dynamicznie rozwijających się wokół miejskich biegunów wzrostu, sprzęgniętych z ich dynamicznym rozwojem $^{1}$, istnieją obszary problemowe, zajmujące o wiele większą przestrzeń,

Prof. dr hab. Maria Halamska, Instytut Rozwoju Wsi i Rolnictwa PAN, ul. Nowy Świat 72, 00-330 Warszawa, m.k.halamska@uw.edu.pl.

1 Obszary funkcjonalnie miejskie ośrodków wojewódzkich zostały wydzielone przez Ministerstwo Rozwoju Regionalnego w 2013 r. 
bardzo często peryferyjnie usytuowane i mające wiele cech świadczących o ich marginalizacji. Tym połączeniem - marginalności i peryferyzacji - posługują się często planiści przestrzenni:

w kontekście polityki regionalnej i ogólnej przestrzenno-społecznego wymiaru marginalizacji i wykluczenia stosuje się też słowo „peryferyzacja”, np. w planie zagospodarowania przestrzennego jednego $\mathrm{z}$ województw [można znaleźć stwierdzenie - M.H.]: „w strefach, które z powodu historycznie ukształtowanego opóźnienia cywilizacyjnego i recesji okresu transformacji ustrojowej wymagają aktywizacji przy pomocy czynników zewnętrznych, inaczej grozi im trwała peryferyzacji i marginalizacja" (Szarfenberg 2008, s. 6).

Niniejszy artykuł traktuje o wiejskich obszarach problemowych i stawia pytania o ich dalszy rozwój, czy bardziej precyzyjnie: politykę ich rozwoju. Punktem wyjścia jest diagnoza ich kondycji, przede wszystkim społecznej. Ukazuje ona ich niektóre społeczne charakterystyki, stawia pytania o endogeniczne zasoby rozwojowe oraz możliwości wykorzystania przez nie wsparcia zewnętrznego. Pod dyskusję - proponując paradygmat dopasowania - poddaję problem dalszego rozwoju w sytuacji postępującego ich regresu ekonomicznego i społecznego.

\section{Obszary problemowe: próba teoretycznego umiejscowienia}

Procesy marginalizacji ${ }^{2}$, analizowane zwykle w odniesieniu do jednostek czy zbiorowości społecznych, dotyczą także całych układów terytorialnych. Ten ich stan, oznaczający zarazem ich peryferyjność (jak i degradację i podległość) jest często - zdaniem Freda Mahlera - wynikiem złego rozwoju (maldevelopment) (Mahler 1993). W ostatnich latach przedstawiciele nauk społecznych opisali wiele ich cech, które często są enumeracją występujących tu braków, pojawiających się problemów, specyfiki sposobu ich funkcjonowania oraz rozwoju; są zazwyczaj nazywane obszarami problemowymi. Marek Proniewski (2014) pisze, że region peryferyjny jest określany jako region: problemowy, marginalny, słabo rozwinięty gospodarczo, depresyjny itp. Regiony peryferyjne charakteryzują się niskimi

$2 \mathrm{Na}$ temat marginalisation (ang.), l'exlusion sociale (fr.), marginalizacji istnieje obszerna literatura. Podkreśla się, że jest to zjawisko wielowymiarowe: ekonomiczne, socjologiczne, kulturowe i polityczne (Silver 1994). W związku z tym definicje zjawiska dzieli się na analityczne, robocze i oficjalne (Grotowska-Leder 2005). Komisja Europejska definiuje wykluczenie społeczne jako proces, w wyniku którego osoby są wypychane na peryferie społeczeństwa; Ministerstwo Polityki społecznej uważa, że „wykluczenie społeczne to sytuacja uniemożliwiająca lub znacznie utrudniająca jednostce lub grupie zgodne z prawem wypełnianie ról społecznych, korzystanie z dóbr publicznych i infrastruktury, gromadzenie zasobów i zdobywanie dochodów w godny sposób" (Nowak 2012, s. 21). 
wskaźnikami ze strefy społeczno-ekonomicznej, wykazując nawet stagnację gospodarczą. Cechują się niekorzystnymi perspektywami rozwoju, w tym w zakresie podniesienia poziomu życia mieszkańców. Wszystkie te cechy można znaleźć w syntetycznej definicji wykluczenia społecznego (por. Szarfenberg 2006, s. 30).

Określenie „obszary problemowe” pojawia się w Polsce w opracowaniach naukowych od lat 90. XX w. ${ }^{3}$ Anna Karwińska definiuje obszary problemowe jako

tereny, na których osiąganie założonych celów rozwojowych zakłócane jest w sposób trwały przez rozmaite czynniki, a ich oddziaływanie nie może być minimalizowane czy eliminowane bez pomocy z zewnątrz. [...] Obszar może mieć charakter problemowy także dlatego, że powstają problemy z samym sformułowaniem celów rozwojowych mieszczących się w ogólnych strategiach przyjmowanych dla kraju (2008, s. 237).

Określenie to pojawia się także w różnych dokumentach oficjalnych w Polsce od końca XX w., kiedy zaczyna dochodzić do głosu koncepcja rozwoju terytorialnego, a nie branżowego czy sektorowego. Takie credo znajdujemy na przykład w Koncepcji przestrzennego zagospodarowania kraju 2030 (2012, s. 182), gdzie stwierdza się, że procesem, jakiemu podlegają współczesne polityki publiczne w świecie, ,jest przechodzenie od podejścia sektorowego do zintegrowanego podejścia terytorialnego". Natomiast z ustawy o planowaniu przestrzennym wynika konieczność wyznaczenia „obszarów problemowych”. W tymże dokumencie za takie obszary uznano: regiony wschodnie obejmujące województwa warmińsko-mazurskie, podlaskie, lubelskie, podkarpackie; Pomorze Środkowe oraz Górny Śląsk; poza Górnym Śląskiem są to obszary wiejskie.

Wspomniana Koncepcja... wymienia dwa typy obszarów funkcjonalnych: miejskie oraz wiejskie. Drugie zaś dzieli na dwa rodzaje: „funkcjonalne obszary wiejskie uczestniczące w procesach rozwojowych” oraz „obszary wymagające wsparcia procesów rozwojowych" (rys. 1). Te ostatnie są definiowane jako

takie obszary, do których czas dojazdu z miasta przekracza 90 minut, a sieć małych i średniej wielkości miast jest słabo rozwinięta (Polska Wschodnia), bądź też istniejące ośrodki miejskie, które w wyniku procesów rozwojowych utraciły wiele z dawniej istotnych funkcji gospodarczych (np. Pomorze Środkowe, północne Mazury, wyspowo w centralnej Polsce). Obszary te w znikomym stopniu uczestniczą we współczesnych procesach rozwojowych. Oferują niedochodowe miejsca pracy, głównie w rolnictwie i w sektorze publicznym (podstawowe usługi

3 Przykładem może być opracowanie pod redakcją Andrzeja Rosnera (2000) czy podręcznik akademicki Anny Karwińskiej (2008). 
w zakresie administracji, edukacji, zdrowia itp.) oraz uzupełniająco w innych sferach gospodarki, dodatkowo narażone są na wahania sezonowe (turystyka) i zagrożone likwidacją w warunkach dekoniunktury. Duża część mieszkańców jest nieaktywna zawodowo ze względu na zaburzoną strukturę demograficzną (emigracja zarobkowa), wynikającą również z braku alternatywnych źródeł dochodów (ukryte bezrobocie strukturalne na wsi) (s. 193).

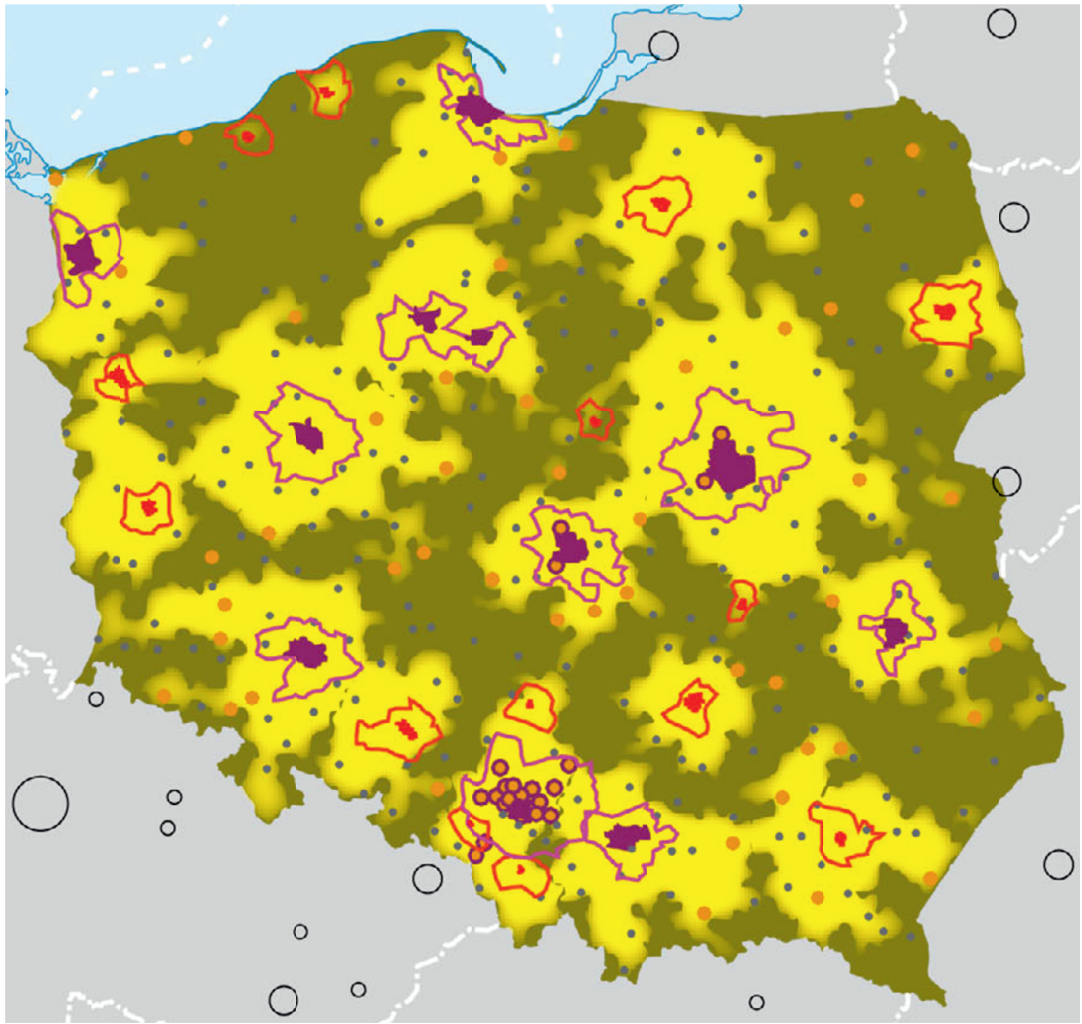

Wiejskie obszary funkcjonalne

$\square$ uczestniczące w procesach rozwojowych

wymagające wsparcia procesów rozwojowych

Rysunek 1. Wiejskie obszary funkcjonalne

Figure 1. Rural functional areas

Źródło: Koncepcja... , s. 196.

Source: Koncepcja..., p. 196.

Najłatwiej zauważalną cechą tych obszarów jest ich peryferyjność, będąca zjawiskiem wieloaspektowym. Narzuca się przestrzenne, geograficzne rozumienie 
peryferyjności, ale używa się też kryterium ekonomicznego, kiedy o peryferyjności decyduje niski poziom rozwoju ekonomicznego (kryterium peryferyjności w polityce spójności UE). Peryferyjność jest postrzegana także przez pryzmat procesów społeczno-ekonomicznych, kulturowych, polityczno-administracyjnych. W nieprzestrzennych koncepcjach peryferyjności regionów wymienia się: słabo rozwiniętą infrastrukturę społeczeństwa informacyjnego, niski poziom kapitału ludzkiego, fragmentaryczne powiązania sektora małych i średnich przedsiębiorstw, słaby kapitał społeczny, zwłaszcza pomostowy. Obszary peryferyjne to obszary wielu występujących problemów społecznych. Peryferyjność jest przy tym pojęciem względnym, gdyż zawsze jest definiowana w stosunku do centrum, a ono samo jest historycznie zmienne, dotyczy różnych dziedzin życia społecznego (centrum gospodarcze, kulturalne, mody itp.), jest swoiście hierarchiczne, gdyż także obszary peryferyjne mają swoje centra. Typologia Steina Rokkana (1980) wymienia peryferia stykowe, enklawy, niedoszłe centra oraz peryferia zewnętrzne (za: Zarycki 2011, s. 35). Ta perspektywa analizy pozwala nie tylko na ukazanie nierówności społecznych, ale przede wszystkim zwraca uwagę na wieloaspektowy problem zależności / podporządkowania / podległości peryferii i centrum. To teoretyczne usytuowanie obszarów problemowych zwraca uwagę na ich cechy oraz możliwości rozwoju, najczęściej odwołujące się do teorii rozwoju zależnego.

Osadzenie rozwoju obszarów problemowych na osi centrum-peryferie nie ma tu charakteru wartościującego, lecz charakter poznawczy i pozwala na pełniejszą diagnozę ich kondycji ${ }^{4}$. „Problemowość” tych obszarów jest definiowana przede wszystkim przez różnego rodzaju deficyty, przy czym najczęściej zwraca się uwagę na deficyty materialne: brak lub odległość od dynamicznych miast, brak dogodnej komunikacji, brak (dobrze płatnych) miejsc pracy, brak młodych, bo emigrują. Wśród deficytów rzadko (lub wcale nie) wymienia się deficyty społeczne i kulturowe, zawarte w strukturze i kulturze społecznej. A przecież immanentną cechą peryferii jest pewien kształt społecznego środowiska, na które składają się elementy społeczne i psychologiczne. Tomasz Zarycki (2010) proponuje, aby peryferyjność i centralność traktować jako „kontekst interpretowanych zachowań społecznych”. Bohdan Jałowiecki zwraca na to uwagę, pisząc, że „bycie na peryferiach powoduje nie tylko deprywację ekonomiczną i społeczną, ale także wpływa na «stan umysłu». Może wzbudzać chęć zmiany sytuacji i wyrwania się ze swojego środowiska, ale może także, częściej, skłaniać do rezygnacji i swoistego waloryzowania peryferyjnej mentalności" (Jałowiecki, Kapralski 2011, s. 9). Dodaje,

4 Na przykład Zarycki (2010, s. 25) uważa, że „trafne rozpoznanie własnej peryferyjności, podrzędności lub zależności w różnych wymiarach i zakresach nie musi automatycznie przekładać się na pogłębianie kompleksów niższości albo obniżenia poziomu aspiracji”, ale może skutkować „dopasowaniem do niej rozwiązań w sferze polityki gospodarczej, naukowej i społecznej”. 
że jest to „nieprzystosowanie się do współczesności” w wymiarze materialnym i mentalnym, choć w moim przekonaniu jest to raczej swoiste przystosowanie się do niej, co przejawia się w ideologii „tutejszości”, sprzyjającej akceptacji czy wręcz legitymizującej peryferyjny status (Babiński 1997). „Tutejszość” to także cecha lokalnych elit; ich stygmatyzacja peryferyjnością znajduje odbicie nie tylko w specyficznym dyskursie, ale także w postrzeganych możliwościach rozwoju. „Aktorzy peryferyjni są co prawda w takim ujęciu relatywnie uzależnieni od centrum, ale spektrum ich możliwych działań nie jest mniejsze, choć inne, niż spektrum aktorów centralnych" (Zarycki 2010, s. 9). Pełnią też oni funkcje pośredników między centrum a peryferiami: reprezentując centrum na peryferiach i przekładając problemy peryferii na kody centrum, co daje im specyficzną pozycję na peryferiach. Tych pośredników Henri Mendras (1976) nazywał notablami, a teorie dependystyczne określają ich mianem „elit kompradorskich”, mających negatywne konotacje.

To usytuowanie pozwala także pokazać - obficie w literaturze opisaną - specyfikę tego rozwoju. Powszechnie znane są reguły rozwoju zależnego, rozwoju egzogennego, opartego na kapitałach zewnętrznych. Pułapki takiego rozwoju celnie charakteryzują Mateo Marini i Patrick Mooney (2006). Gospodarki zależne to terytorialne układy gospodarcze, których funkcjonowanie i dochody ludzi zależą przede wszystkim od czynników (inwestycji) zewnętrznych, prywatnych (fabryka) lub publicznych (państwowy sektor usług). Prywatny sektor rozwija się tam, gdzie siła robocza jest tania, a otoczenie „przyjazne”; państwowy, lokowany za sprawą decyzji politycznych, tam, gdzie otoczenie jest nieprzyjazne i brakuje innych perspektyw rozwoju. Tam umiejscawia się więzienia, czasem ośrodki pomocy socjalnej, domy specjalne, wysypiska śmieci etc. Koniec końców takie gospodarki są słabe, ponieważ brak jest lokalnej kontroli nad źródłem inwestycji: fabrykę zawsze można przenieść tam, gdzie jest jeszcze tańsza siła robocza, co jest dość typowe dla obecnej fazy globalizacji. Z kolei los inwestycji państwowych zależy od stanu budżetu i kondycji ekonomicznej państwa. W społecznościach, gdzie dominuje taka gospodarka, stosunki społeczno-polityczne odpowiadają stosunkom we „wsi klientelistycznej” według typologii Terry’ego Marsdena (et al. 1993). Niektóre badania co prawda wskazują, że produktem ubocznym ulokowania wielkich inwestycji może być wyuczenie się przez populację lokalną zachowań i postaw przedsiębiorczych, co może potem sprzyjać rozwojowi endogennemu; zwracały na ten fakt uwagę nowsze, „optymistyczne” teorie dependystyczne.

Gospodarki peryferyjne cierpią na deficyt innowacji, których nie tylko nie są w stanie wytworzyć, ale często nawet w pełni przyswoić. Często wprowadzana innowacja $w$ toku adaptacji na peryferiach ulega deformacji. 
Działa tu dwojaki mechanizm. Po pierwsze, w zderzeniu z kulturą peryferii zaczyna działać selekcja eliminująca wyższe wartości i bardziej wyrafinowane. To, co przyjmuje się najłatwiej, to najprostsze, najbardziej powierzchowne, by nie powiedzieć najbardziej prymitywne, fragmenty kultury. [...] Drugi mechanizm deformacji to kompromisowe uzgadnianie treści płynących z zewnątrz z lokalnymi zwyczajami i tradycjami. Na przykład w tradycyjnie autokratycznym społeczeństwie import instytucji demokratycznych prowadzić może do demokracji fasadowej, pałacowej, ograniczonej do frakcji popleczników czy „dworu” [...] (Sztompka 2003, s. 594).

Postulowany współcześnie rozwój endogenny (neoendogenny) bywa przede wszystkim kierowany na wzmocnienie czy unowocześnienie zasobów endogennych, co nie zawsze przynosi oczekiwane rezultaty. Przykładem może być polityka rozwoju peryferyjnych wiejskich terenów Portugalii, bazująca na ideach i środkach europejskiej polityki spójności (Grosse 2007), która jednak nie przynosi oczekiwanych rezultatów (Halamska 2004). Polityka rozwoju wiejskich obszarów peryferyjnych bardzo ją przypomina; jest polityką reaktywną wobec wyzwań europejskich, skierowaną na maksymalną absorbcję środków UE (por. Knieć 2012).

\section{Wiejskie obszary problemowe: charakterystyka deficytów}

Wiejskie obszary problemowe zajmują więcej niż trzecią część wiejskiego terytorium kraju. Warto bliżej przeanalizować poziom i typ ich rozwoju gospodarczego. Andrzej Rosner i Monika Stanny (2016), analizując poziom rozwoju gospodarczego, biorą pod uwagę 11 elementów, takich jak: dostępność przestrzenna, stopień dezagraryzacji gospodarki lokalnej, sektor rolniczy, sektor pozarolniczy, lokalne finanse publiczne, stopień zrównoważenia rynku pracy, problematyka demograficzna, edukacyjna, aktywność społeczna, zamożność i spójność społeczności lokalnej, elementy warunków mieszkaniowych. Nadając im odpowiednie wagi, wyróżniają pięć poziomów rozwoju społeczno-gospodarczego obszarów wiejskich w Polsce: bardzo niski, niski, średni, wysoki i bardzo wysoki. Analiza usytuowania przestrzennego (rys. 2) wskazuje, że zdecydowana większość gmin leżący na obszarach problemowych legitymuje się „bardzo niskim” lub „niskim” poziomem rozwoju. Na ten bardzo niski lub niski poziom rozwoju składają się: słaba dostępność komunikacyjna $\mathrm{z}$ otoczeniem zewnętrznym i wewnątrz gminy, wysoki stopień agrarności gospodarki (mierzony udziałami rolniczych miejsc pracy i źródeł utrzymania), niskie dochody własne gmin, niekorzystne procesy demograficzne (emigracja) oraz struktura zdeformowana struktura demograficzna („stara” struktura wiekowa, niedobór kobiet w młodszych kategoriach wiekowych oraz niekorzystne wskaźniki 
demograficzne (urodzeń, przyrostu naturalnego), brak pracy na lokalnym rynku lub jego mała atrakcyjność, niski poziom kapitału ludzkiego (spowodowany najczęściej emigracją młodych lepiej wykształconych), brak społecznej aktywności, niskie dochody ludności, będące w dużej mierze funkcją struktury zatrudnienia (rolnictwo) oraz wieku (świadczenia socjalne).

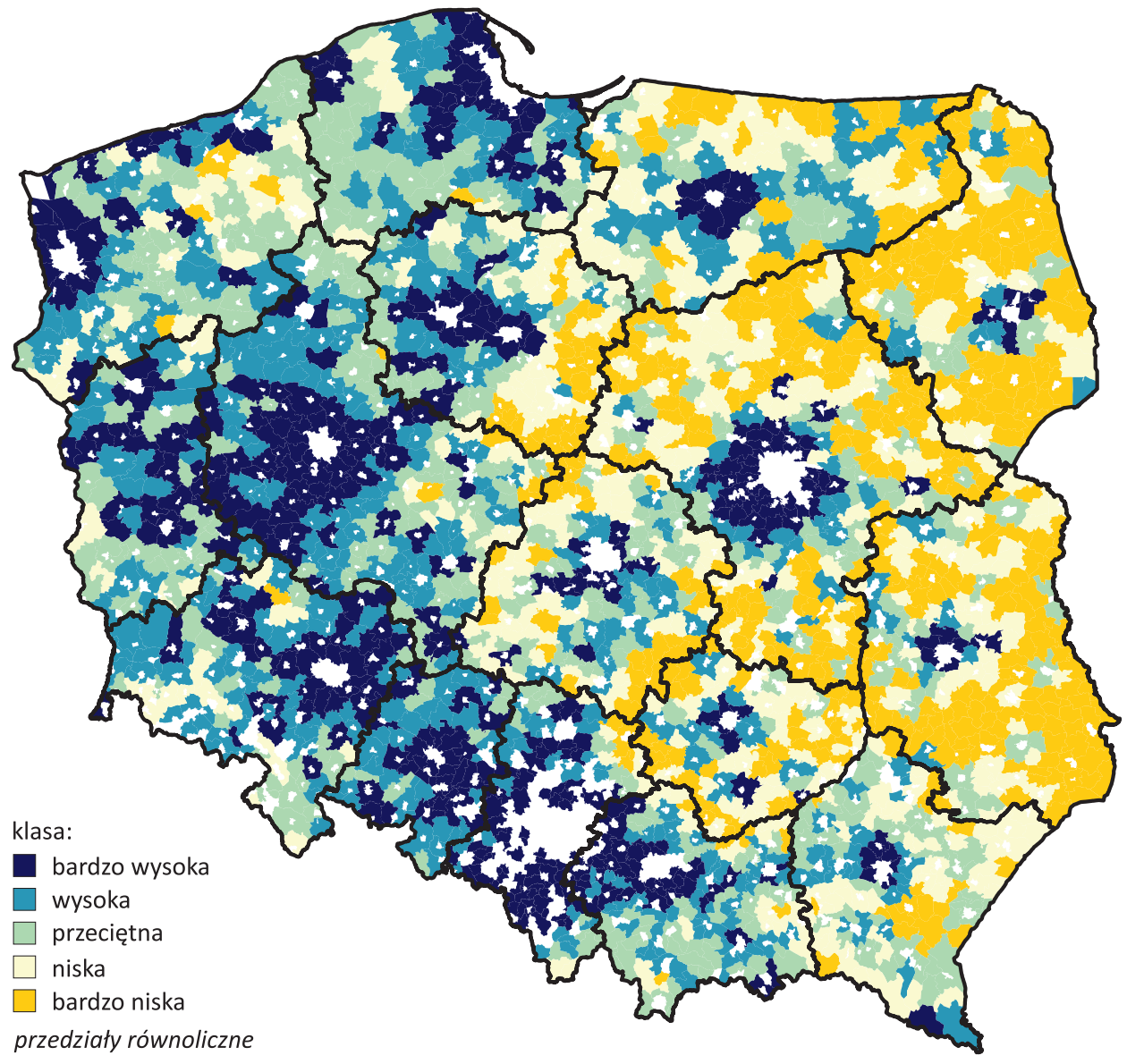

Rysunek 2. Poziom rozwoju społeczno-gospodarczego według wskaźnika syntetycznego

Figure 2. Level of socio-economic development according to a synthetic index

Źródło: Rosner, Stanny 2016, s. 37.

Source: Rosner, Stanny 2016, p. 37.

Dodatkowych informacji o charakterze obszarów problemowych dostarcza struktura gospodarki lokalnej. Rosner i Stanny wyróżniają siedem jej typów: 
1 - gospodarka zdominowana przez rolnictwo tradycyjne; 2 - przez rolnictwo wielkoobszarowe; 3 - gospodarka lokalna z przewagą funkcji rolniczych; 4 - gospodarka zróżnicowana z obecnością rozdrobnionego rolnictwa; 5 - zrównoważona wielofunkcyjna gospodarka lokalna; 6 - wielofunkcyjna gospodarka o zredukowanych funkcjach rolniczych; 7 - gospodarka pod silnym wpływem miasta (silnie zurbanizowana). Przestrzenny rozkład tych typów gospodarki (rys. 3) jednoznacznie wskazuje, że na obszarach problemowych gospodarka jest oparta przede wszystkim na rolnictwie: tradycyjnym rodzinnym, także - choć nie zawsze - rozdrobnionym, oraz rolnictwie wielkoobszarowym, zdominowanym przez wielkie rynkowe struktury produkcji. Mniejszy udział mają tu gospodarki zróżnicowane, lecz dość słabe, gdzie widoczny jest wpływ rozdrobnionego rolnictwa.

dominacja rolnictwa tradycyjnego (typ 1)

dominacja rolnictwa wielkoobszarowego (typ 2)

przewaga funkcji rolniczej, pośrednie (typ 3)

wielodochodowe, rozdrobnione rolnictwo (typ 4)

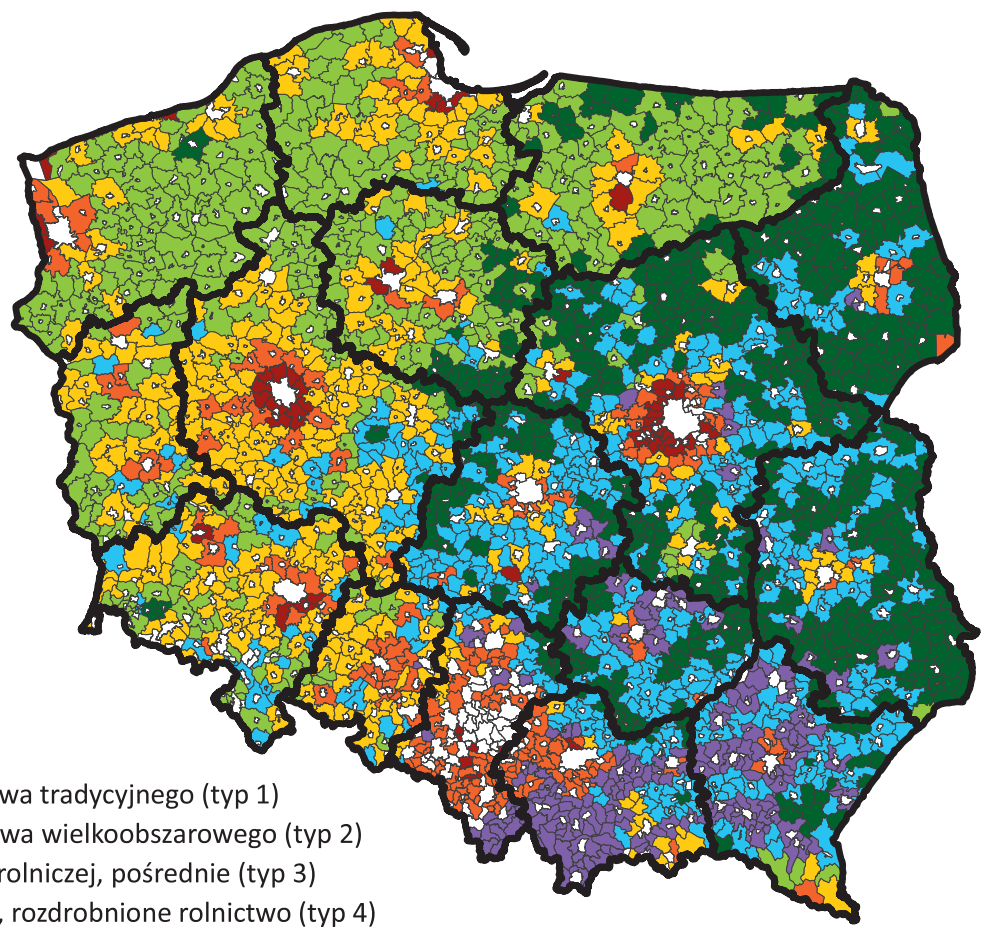

wielofunkcyjne, równowaga sektorów (typ 5)

zurbanizowane, redukcja funkcji rolniczej (typ 6)

silnie zurbanizowane (typ 7)

Rysunek 3. Typy struktury gospodarki lokalnej według wskaźnika syntetycznego Figure 3. Types of structures of local economies according to a synthetic index

Źródło: Rosner, Stanny 2016, s. 42.

Source: Rosner, Stanny 2016, p. 42. 
Ze strukturą gospodarki związana jest struktura społeczna. Gminy o zróżnicowanej, wielofunkcyjnej gospodarce, gminy zurbanizowane znacznie bardziej nasycone są klasą średnią i pracownikami usług, a znacznie rzadziej spotkać można przedstawiciela zawodów rolniczych. Przy prawie identycznych wskaźnikach wykształcenia zwracają tu także uwagę wyższe dochody osobiste w prawie wszystkich grupach społeczno-zawodowych. Największe różnice istnieją między grupa specjalistów w obydwu typach obszarów, najmniejsze w grupie pracowników biurowych. Wskazuje to na istnienie odmiennego rynku pracy na obszarach wielofunkcyjnych zurbanizowanych oraz łatwego dostępu do miejskiego rynku pracy, oferującego lepsze zarobki i większe możliwości kariery zawodowej ${ }^{5}$.

Konsekwencją różnic w strukturze społecznej są odmienne postawy oraz typy społecznej i obywatelskiej aktywności, gdyż zależą one od społecznego składu ludności zamieszkującej te obszary oraz od „społecznego wyposażenia” przedstawicieli różnych grup społecznych, ich kapitału społecznego i kulturowego. To - jak pokazują analizy - klasa średnia ma wiele cech, które przekładają się na jej większy kapitał społeczny i kulturowy, zasoby wyraźnie sprzyjające rozwojowi. Widać tu podział wewnątrz wsi, a linia podziału przebiega między wiejską klasą średnią a „klasami ludowymi": robotnikami i rolnikami. To bliskie sobie segmenty struktury, korzenie tego zjawiska tkwią w chłopskiej genealogii znacznej części robotników, życiu na wsi, często także w związkach $\mathrm{z}$ gospodarstwem rolnym. Ta bliskość owocuje także podobieństwem zachowań i poglądów. Wiejska klasa ludowa, składająca się z rolników i robotników, jest dość spójna, jednolita. Również w swoich poglądach i postawach. Odmienna w swojej kulturze obywatelskiej jest nowa klasa średnia, najbardziej aktywnie uczestnicząca w życiu wiejskiej społeczności, bardziej wrażliwa na dobro wspólne, mniej kseno- i homofoniczna i bardziej przekonana do zalet demokracji. Ona też ma mocniej zróżnicowane i przestrzennie rozproszone kontakty towarzyskie, co w sumie owocuje inną, bardziej otwartą wizję świata i stanowi cenny kapitał pomostowy (por. Halamska 2016).

Charakteryzowane tu wiejskie obszary problemowe to obszary peryferyjne; przestrzenny, geograficzny wymiar tej peryferyjności to tylko jeden z wymiarów wiejskiej peryferyjności. O ich peryferyjności decydują przede wszystkim deficyty, składające się stan endogenicznego potencjału. To deficyty kapitału fizycznego, ludzkiego, społecznego, a także, na co wskazują niektóre opracowania, deficyt innowacyjności i przedsiębiorczości (Grosse 2007, s. 103). Szczególną wagę przypisać należy deficytom ludzkim i społecznym, wynikającym ze społecznego składu wiejskich zbiorowości, które w konsekwencji owocują rozpowszechnionymi postawami niesprzyjającymi rozwojowi (por. Grondona 2003). I te deficyty społeczno-kulturowe są najtrudniejsze do uzupełnienia.

\footnotetext{
5 Szczegółowa charakterystyka znajduje się w Halamska, Stanny, Hoffmann (2017).
} 


\section{O niektórych cechach modelowego rozwoju wiejskiego w XXI wieku}

Rozwój wiejski w Europie przez bez mała cały wiek XX można określić mianem poszerzonego rozwoju rolnictwa. Ta koncepcja, oparta na dyfuzji innowacji i mechanizmach modernizacji, zakładała, „że rolnictwo stanowi podstawową lub centralną aktywność wsi; tym samym akcje na rzecz produkcji rolnej i zatrudnionych w rolnictwie są politykami wiejskimi" (Perrier-Cornet 2001). Modernizacyjne wysiłki podejmowano w różnych częściach globu, mając nadzieję, że wprowadzona innowacja zapoczątkuje serię zmian, które ułożą się w znane sekwencje przemian ekonomicznych, społecznych, politycznych i kulturowych. Znany i opisany był także mechanizm zmiany, gdyż za modernizacją wsi stała wielka socjologiczna teoria modernizacji.

Ale modernizacja rolnictwa przyniosła też wiele nieprzewidzianych skutków, jeśli nie negatywnych, to ambiwalentnych. Modernizacja oznaczała nie tylko wzrost produktywności rolnictwa i powstawanie silnych, konkurujących gospodarstw, lecz była także procesem brutalnej selekcji rolników, którzy nie sprostali jej warunkom. Mechanizacja, intensyfikacja i maszynizacja rolnictwa spowodowała spadek zatrudnienia w rolnictwie, za nim szedł exodus wiejski, co spowodowało wyludnianie się wsi, pustynnienie demograficzne, społeczne i kulturowe obszarów wiejskich. Postępująca technicyzacja i industrializacja rolnictwa prowadziła do skażenia środowiska naturalnego: gleby, wody, powietrza. Rolnictwo ponadto podlegało i podlega procesom denaturalizacji, czego jednym z przejawów jest chociażby powstawanie ogromnych ferm hodowlanych bez zasobów ziemi czy kompleksów rolniczo-przemysłowych. Okazało się więc, że rozwój rolnictwa nie zawsze idzie w parze z rozwojem wsi, czasem wręcz jej szkodzi. Na obszarach wiejskich pojawili się inni mieszkańcy, nierolnicy wybierający wieś jako miejsce do życia czy wypoczynku. Wieś stała się więc miejscem nie tylko produkcji, ale też konsumpcji, niepowiązanym z działalnością rolniczą. Rozwijały się też inne, nierolnicze gałęzie gospodarki wiejskiej. Był to znaczący powód do sformułowania nowych zasad rozwoju obszarów wiejskich, nowego paradygmatu. Stał się nim sustainable rural development.

Koncepcja zrównoważonego rozwoju wiejskiego pojawiła się w konkretnym historycznym i społecznym czasie: globalizacji i powrotu lokalizmu, kryzysu przemysłowego społeczeństwa i jego siły napędowej, produktywizmu oraz kryzysu opiekuńczego państwa dobrobytu. Na jej popularności zaważyło także to, że różnie artykułowana „kwestia wiejska” pojawia się w różnych częściach rozwiniętego, "pierwszego" świata. Przedsiębrane działania mają na celu jej rozwiązanie. Kraje wysoko rozwinięte reagowały na kryzys dotykający wieś w podobny sposób: albo tworząc polityki rozwoju wiejskiego, albo podejmując wiele inicjatyw mających ten 
rozwój stymulować. Te polityki przywoływały również rolnictwo jako element tego rozwoju, choć często jego miejsce nie jest już pierwszoplanowe (por. Halamska, Śpiewak 2008), a ponadto w tej koncepcji podkreśla się nieprodukcyjne, pozarynkowe funkcje rolnictwa: społeczne, kulturowe i przyrodnicze (Wilkin 2010) czy zielone, błękitne i żółte ${ }^{6}$ (Van Huylenbroeck et al. 2003). I te właśnie nowo odkryte funkcje stają się ważnymi elementami nowej koncepcji rozwoju wiejskiego. W Unii Europejskiej koncepcja rozwoju wiejskiego jest integralnie związana z ewolucją Wspólnej Polityki Rolnej, kiedy

historycznie ukształtowany model Wspólnej Polityki Rolnej, prowadząc do negatywnych zjawisk - powiększania nadwyżek produkcyjnych, na przekór istniejącym instytucjom kontrolnym, niemożności podwyższania dochodów rolniczych, na przekór zwiększającym się wydatkom i postępującemu zmniejszaniu się populacji rolniczej, narastania problemów ochrony środowiska, związanych $\mathrm{z}$ rolnictwem typu intensywnego, będącego następstwem powiązania różnych form pomocy z poziomem produkcji, wzrostu kosztów budżetowych (Jurcewicz 2003, s. 75)

przekształca się w model limitowania produkcji, uwzględniający problemy (przyrodnicze i społeczne) środowiska wiejskiego.

Określenie sustainable development, tłumaczone na język polski jako „rozwój trwały i zrównoważony", jest wieloznaczne, zwłaszcza gdy używają go politycy i publicyści, kiedy hasło rozwoju zrównoważonego jest traktowane jako dyrektywa równoważenia rozwoju. Koncepcja rozwoju zrównoważonego nie odnosi się tylko do rolnictwa i wsi, jest dość powszechnie używana.

[Koncepcja ta] dominuje we współczesnych prognozach, planach i analizach scenariuszy dla świata i poszczególnych krajów czy regionów, a nawet gmin czy społeczności lokalnych. Jest ona traktowana jako obowiązujący obecnie w Unii Europejskiej paradygmat rozwojowy (Knieć 2012, s. 29).

Socjologowie zwracają uwagę, że jest to proces, który zachodzi na kilku płaszczyznach: społecznej, ekonomicznej i ekologicznej. Charakteryzując tę koncepcję, Tomasz Adamski i Krzysztof Gorlach (2007) stwierdzają, że rozwój zrównoważony to (1) rozwój uczestniczący, w który systematycznie angażują się członkowie społeczności i instytucje społeczeństwa obywatelskiego, oparty na (2) zrównoważeniu ekonomicznym, tj. utrzymywaniu kapitału w stanie nieuszczuplonym, to

6 Zielone to zarzadzanie zasobami ziemi, utrzymanie bioróżnorodności, błękitne - zarządzanie zasobami wodnymi, żółte - utrzymywanie spójności i żywotności obszarów wiejskich (por. Wilkin 2010, s. 29). 
„nieekspansywna strategia ekonomiczna, ograniczająca konsumpcję oraz zyski w imię ograniczenia ryzyka pozostania bez wystarczającej liczby wyjściowych zasobów" (s. 142) oraz (3) respektujący wartości ekologiczne: umiarkowanego wykorzystania zasobów naturalnych oraz ich ochronę przed zanieczyszczeniem. Nie jest to zatem, jak niektórzy mylnie przypuszczają, rozwój równoważony, kiedy władza publiczna przez redystrybucję środków wspiera rozwój obszarów słabiej rozwiniętych, aby nie dopuścić do drastycznych różnic w rozwoju, lecz rozwój, który winna cechować harmonia między jego trzema wyżej wymienionymi płaszczyznami. Nie dominują tu także problemy ekologiczne, a utożsamianie rozwoju zrównoważonego z ekorozwojem też jest błędem, choć problem zniszczenia środowiska naturalnego wyraźnie przyczynił się do sformułowania tej koncepcji.

Rozwój trwały i zrównoważony to koncepcja wielowymiarowa, której realizacja powinna uwzględniać zasady trwałości, samopodtrzymywania (sustainability) oraz zintegrowania.

Zasadniczy postulat kryjący się w pojęciu rozwoju zrównoważonego wskazuje zatem na konieczność przyjęcia takiej strategii przeobrażeń, która nie niszczy zlokalizowanych na określonym obszarze naturalnych, ekonomicznych i społecznych zasobów, umożliwiając tym samym kontynuowanie rozwoju w przyszłości. W tym sensie pojęcie zrównoważenia oznacza równowagę pomiędzy interesami obecnych i przyszłych użytkowników. Jest to pierwszy element idei rozwoju zrównoważonego, kładący nacisk na trwałość (Adamski, Gorlach 2007, s. 142).

Drugi wymiar idei to nacisk na równowagę pomiędzy rozmaitymi kierunkami przemian, gdyż równomierny rozwój wielu kierunków (wielofunkcyjność gospodarki) stanowi o możliwości samopodtrzymywania rozwoju, kiedy kryzys w jednej gałęzi gospodarki może rekompensować prosperity w jej innej gałęzi. I w koń$\mathrm{cu}$ - idea zrównoważenia wskazuje na konieczność wspomagania, równoważenia, integrowania środków wewnętrznych i zewnętrznych, konieczność kombinacji endo- i egzogennych czynników i strategii rozwoju.

Sustainable rural development odwołuje się więc do wielu elementów koncepcji rozwoju neoendogennego; rozwoju, który ma się opierać na własnych, endogennych zasobach, a zewnętrzne wspomaganie ma służyć ich uruchomieniu, aktywizacji. W moim przekonaniu taka właśnie zasada powinna być najważniejsza przy wspieraniu rozwoju wiejskich obszarów problemowych. 


\section{Wspierać czy zalesiać?}

W świetle wyżej przedstawionych założeń odpowiedź na prowokacyjne pytanie postawione w tytule opracowania staje się bardzo złożona. Przyjmuję, że wydzielenie obszarów wymagających wsparcia jest krokiem poprzedzającym konkretne działania wspierania rozwoju. Wymaga to odpowiedzi na szereg pytań. Także na pytanie pochodne: do jakiego momentu należy ten rozwój wspierać, to znaczy kiedy rozwój osiągnie poziom satysfakcjonujący (dla kogo: wspomagających?, wspomaganych?). Z paradygmatu trwałego zrównoważonego rozwoju wiejskiego wynika, że tym momentem powinno być osiągnięcie stanu samopodtrzymywania się rozwoju, kiedy nie będzie on już wymagał wspomagania przez środki zewnętrzne. Okres wspomagania nie może być tu z góry określony, lecz powinna go wyznaczać osiągnięta samodzielność. Istotne staje się zatem pytanie, czy wszystkie wiejskie obszary problemowe mają szanse na realizację tego celu. Jeśli nie, to jak wydzielić te, które takie szanse mają, oraz te, które są ich pozbawione?

Co powinno o takim podziale decydować? Można rozważyć wpływ dwóch rodzajów czynników: zasobów endogenicznych obszarów oraz dynamiki dotychczasowego rozwoju. Zasoby własne, endogeniczne, nie zawsze są odpowiednio postrzegane, definiowane, waloryzowane i wykorzystywane; jest to procesem bardzo złożonym i uzależnionym od cech lokalnej elity. Ukazuje to rozwijana we Francji koncepcja économie de proximité. Zakłada ona, że kluczowe znaczenie dla rozwoju lokalnego ma posiadany przez społeczność lokalną kapitał, związany z danym terytorium, gdyż społeczność lokalna jest zawsze terytorialnie zakotwiczona oraz charakteryzuje się relacjami społecznymi wynikającymi z bliskości. Można zatem założyć, że „każdy obszar (terytorium) zawiera potencjały rozwojowe, które społeczny projekt może, po rozpoznaniu i mobilizacji, przekształcić w aktywa rynkowe lub źródła wartości ekonomicznych" (Lacquement, Chevalier 2016, s. 495). Te zasoby mogą być materialne i niematerialne, wskazane przez jednostki czy zbiorowość. Ekonomia bliskości stoi na stanowisku, że zasoby lokalne powstają w procesie społecznej konstrukcji i są związane ze strategią adaptacji gospodarki lokalnej do wymogów gospodarki globalnej. Są wytwarzane na drodze długiego ewolucyjnego procesu i uzależnione od doświadczenia i kompetencji aktorów rozwoju (zwłaszcza ich zdolności tworzenia wizji, możliwości projekcji przyszłości). Oznacza to, że nie wszyscy aktorzy lokalnej sceny są jednakowo znaczący w procesie identyfikacji i waloryzacji zasobów. Szczególne znaczenie ma obecność środowiska innowacyjnego, które Guillaume Lacquement i Pascal Chevalier uznają za niezbędny element w analizie współczesnego rozwoju lokalnego, pozwalający zrozumieć jego mechanizmy. Koncepcja ta wyróżnia dwa rodzaje zasobów: ogólne (génériques) oraz specyficzne (spécifiques). Zasoby ogólne występują wszędzie, są powszechne i nie są 
przez lokalizację powiązane $\mathrm{z}$ danym terytorium; zasoby specyficzne są związane z miejscem w sposób konieczny, z nim identyfikowane i przez nie rozpoznawane, co stwarza przewagę komparatywną i zwiększa konkurencyjność lokalnej produkcji oraz ułatwia integrację gospodarki lokalnej z globalną. W koncepcji ważne jest nie tylko rozpoznanie (identyfikacja) zasobu, ale też jego waloryzacja (kwantyfikacja i ocena), gdyż od niej zależy sposób wykorzystania w procesie rozwoju, nazywany w koncepcji trajektoriami zasobów. Tu zaś warto wyróżnić przede wszystkim trajektorię banalizacji, w istocie rzeczy niweczącej specyficzny zasób, oraz trajektorię specyfikacji, sprzyjającą rozwojowi (Peyrache-Gadeau, Pecqueur 2004). Środowisko takie rozwija w sposób autonomiczny zróżnicowane zasoby specyficzne i jest zdolne sformułować projekt i strategię rozwoju lokalnego.

Tu można postawić dalsze, przewrotne pytanie: czy zacofanie, niedorozwój stanowić może rentę, która wspomoże czy zadecyduje o dalszym rozwoju? Odpowiedź wcale nie jest jednoznaczna. W moim przekonaniu niedorozwój może się stać czynnikiem rozwoju w sytuacji, gdy zostanie zdefiniowany jako zasób (np. dla wiejskiej turystyki) i wykorzystany w strategii rozwoju. Może on także sprzyjać pewnym typom rozwoju (por. Woś, Zegar 2002), mającym znaczenie konserwacyjne (np. utrzymanie ziemi rolniczej w dobrej kondycji). Nie wydaje mi się jednak, by upoważniał do braku jakichkolwiek działań czy poprzestania tylko na działaniach podtrzymujących stan niedorozwoju ${ }^{7}$.

Zasobem jest też dotychczasowa dynamika zmian. Między obszarami głównie rolniczymi a wielofunkcyjnymi i zurbanizowanymi ciągle istnieją znaczne różnice, ale w ciągu dziesięciolecia 2003-2013 zmniejszały się (zbliżenie nastąpiło w strukturze źródeł utrzymania, malał dystans w dochodach poszczególnych grup społeczno-zawodowych) lub pozostawały na tym samym poziomie (wskaźnik wykształcenia). Oznacza to, że zmiany w tym okresie były bardziej dynamiczne na obszarach głównie rolniczych, które „doganiały” wielofunkcyjne zurbanizowane (por. Halamska, Stanny, Hoffmann 2017). Wynika stąd, że na tych obszarach istnieje pewien potencjał, na którym może opierać się ich dalszy rozwój. Nie jest on jednakowy we wszystkich gminach, na co wskazuje bardziej szczegółowa analiza

7 Obce jest mi na przykład rozumowanie Tadeusza Popławskiego, który pisze: „Raymond Aron, znany francuski politolog, w swoje książce, która legła u podstaw teorii konwergencji, [...] dostrzegł, że błędem komunizmu było nienadążanie rolnictwa za rozwojem przemysłu, wymuszonym przez trend militarny. Tego błędu nie popełniły kraje kapitalistyczne. Popełniły one jednak inne błędy, których nie musimy powtarzać, zwłaszcza że rządy niektórych państw zaczęly je korygować. Znany jest nam fakt wydatkowania olbrzymich sum rzędu prawie miliarda dolarów przez rząd autonomicznego Quebecu, a także inne prowincje kanadyjskie na [...] odtworzenie czegoś, co właśnie posiadamy jako niemal jedyna świecie w adekwatnej formie. My jeszcze mamy rodzinne gospodarstwa chłopskie [...]. Nie powinniśmy wytwarzać sztucznego rolnictwa, by potem się z niego wycofywać czy zawracać z drogi” (1995, s. 223-224). 
II etapu „Monitoringu obszarów wiejskich” (Rosner, Stanny 2016). W przywołanej analizie wyróżniono cztery profile dynamiki rozwoju:

1. ponadprzeciętną dynamikę rozwoju składowych społeczno-gospodarczych z wyjątkiem aktywności społecznej i elementów wyposażenia infrastrukturalnego; 2 . relatywnie wolną dynamikę przemian w sektorze pozarolniczym, poprawę dostępności przestrzennej i aktywności społecznej; 3. brak równowagi na rynku pracy, niekorzystne zmiany demograficzne, poprawa w zakresie edukacji; 4 . względnie powolna dezagraryzacją gospodarki lokalnej, przy jednoczesnym równoważeniu rynku pracy i poprawie warunków mieszkaniowych, ale niskiej zdolności gmin do kreowania dochodów (Rosner, Stanny 2016, s. 205).

Każdy z typów ma odmienny profil dynamiki. Jeśliby na tej podstawie oceniać zdolności rozwojowe obszarów problemowych, to największe prawdopodobieństwo sukcesu miałyby obszary (gminy) zdominowane przez rolnictwo wielkoobszarowe (por. rys. 2), gdyż aż w połowie $\mathrm{z}$ nich zaobserwowano ponadprzeciętną dynamikę rozwoju.

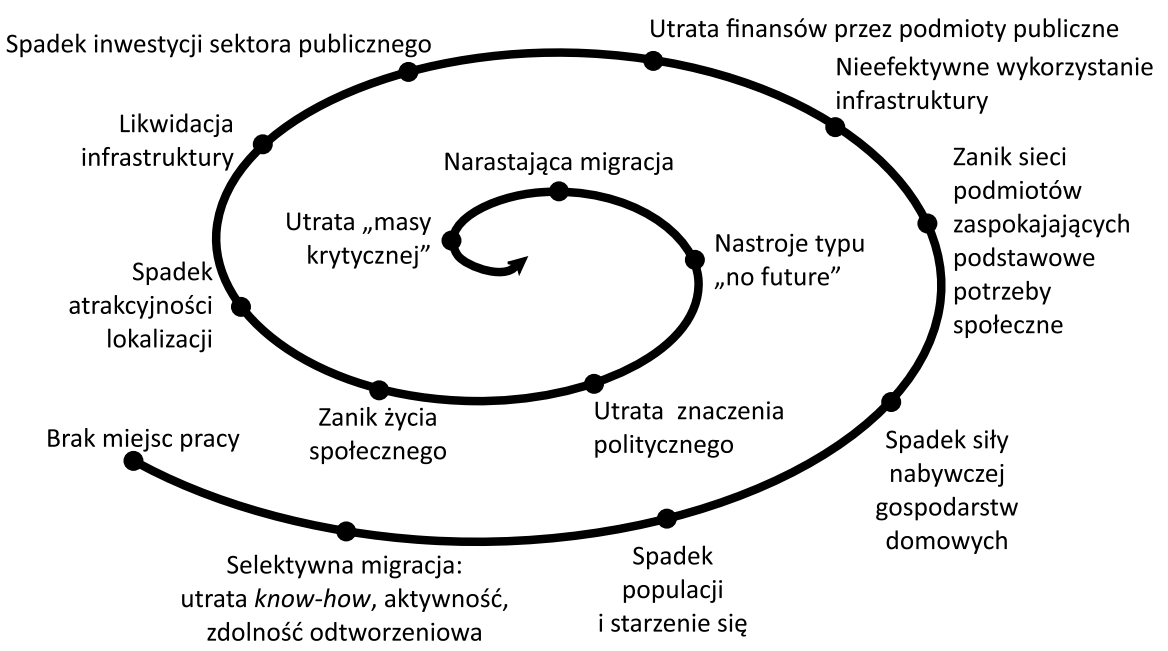

Rysunek 4. Model zanikania wsi (spirala negatywnego rozwoju według Gerlind Weber) Figure 4. The rural disappearance model (the spiral of negative development after Gerlind Weber)

Źródło: Wilczyński 2016, s. 196.

Source: Wilczyński 2016, p. 196.

Te dwa połączone kryteria mogłyby wskazać obszary problemowe, które mają szanse na przełamanie rozwojowego impasu i przez „wielkie pchnięcie i minimalny 
wysiłek własny" na znalezienie się na rozwojowej trajektorii. Działania wspierające powinny przy tym zmierzać do budowania nowego zasobu endogenicznego (z czym może wiązać się zmiana funkcji tych obszarów), a nie tylko unowocześniania zasobów dotychczas istniejących. Analiza takiego właśnie rozwoju opartego tylko na unowocześnianiu zasobów endogenicznych na peryferyjnych obszarach wiejskich Portugalii (Halamska 2005; Grosse 2007) wskazuje, że powstająca w ich wyniku „spontaniczna trajektoria rozwoju jest niewystarczającym czynnikiem pobudzenia rozwoju i wprowadzenia zmian w gospodarce obszarów peryferyjnych" (Grosse 2007, s. 101).

Pozostaje jeszcze problem tych obszarów problemowych, które nie mają szans na rozwój i wykorzystanie „zewnętrznego pchnięcia”, co wynika przede wszystkim z faktu, że nie są one w stanie wykonać owego „minimalnego wysiłku własnego”. Co przedsięwziąć wobec obszarów wiejskich, które mimo już istniejącego, czasem wieloletniego wsparcia nie rozwijają się, lecz zwijają? Jak rozpoznać obszary problemowe, które mają potencjalnie małe szanse na sukces rozwojowy? Jak je wspierać, aby ograniczone środki publiczne na wspomaganie rozwoju najlepiej wykorzystać czy wręcz uniknąć kosztów utopionych i nie kierować środków na obszary, które nie będą w stanie ich wykorzystać? Jak wyodrębnić takie obszary? Pomocna może tu być koncepcja Negative Entwicklungsspirale - spirali negatywnego rozwoju Gerlind Weber (2009), którego konsekwencją jest zanikanie wsi.

Spirala negatywnego rozwoju to scenariusz regresu, a następnie degradacji miejscowości w wyniku spadku liczby mieszkańców oraz zmian w strukturze wiekowej, co prowadzi do zaniku żywotności i utraty niezbędnej do funkcjonowania „masy krytycznej". Przebieg procesu ma charakter wielokrotnych negatywnych sprzężeń zwrotnych następujących po zadziałaniu czynnika wyzwalającego, np. niesatysfakcjonujących warunków życia, niedoboru miejsc pracy, niemożności zaspokojenia wysokich oczekiwań życiowych (Wilczyński 2016, s. 197).

Sam Ryszard Wilczyński - na podstawie obserwacji procesu w województwie opolskim w okresie 1975-2013 - rekonstruuje jego przebieg nieco inaczej. Wyróżnia w nim pięć faz, na które składają się następujące elementy: 1 - selektywny odpływ ludności; 2 - regres gospodarki lokalnej (redukcja siły nabywczej i pogorszenie warunków bytowych ludności, zanikanie podmiotów gospodarczych, nieefektywne wykorzystanie infrastruktury i wzrost kosztów jej utrzymania, spadek wpływów podatkowych i możliwości inwestycyjnych samorządów); 3 - załamanie gospodarki lokalnej i życia społecznego (brak inwestycji komunalnych, likwidacja części infrastruktury, postępujący zanik życia gospodarczego, utrata atrakcyjności lokalizacyjnej); 4 - końcowa migracja (utrata znaczenia politycznego w skali lokalnej, nastroje no future, nasilona migracja ekonomiczna, uzależnienie od transferów socjalnych, degradacja substancji budowlanej i infrastruktury); 5 - upadek (zanikanie tkanki 
budowlanej, infrastruktury, niesamodzielność życiowa pozostałych mieszkańców). Wieś jako struktura osiedleńcza zanika, a kluczowa dla procesu jest faza trzecia, w której potencjał rozwojowy schodzi poniżej poziomu krytycznego do „punktu bez powrotu".

Zanikanie wsi to nowy, złożony proces społeczny, którego korzenie tkwią w procesach demograficznych; przebieg tych procesów oraz ich dynamika mogą więc być wskaźnikami zarówno początku, jak i zaawansowania zanikania wsi. Ich znaczenie uwypukla, przytaczane przez Rosnera i Stanny,

jedno z praw migracji Ravensteina, mówiące, że migracje ludności (per saldo) kierują się z obszarów biedniejszych, gorzej rozwiniętych i niezapewniających akceptowanego społecznego poziomu zaspokajania potrzeb, do obszarów lepiej wyposażonych, rozwiniętych i obiecujących lepsze warunki życia. Ale migracje mają także wpływ na struktury demograficzne zarówno w środowisku odpływu, jak i napływu. Dzieje się tak, gdyż migracje ludności wykazują specyficzną selektywność. Migrują przede wszystkim ludzie młodzi, dobrze wykształceni, zaradni i przedsiębiorczy. W rezultacie w regionach przewagi odpływu migracyjnego pojawiają się specyficzne zjawiska dotyczące struktur demograficznych: starzenie się ludności, niedostatek osób dobrze wykształconych, w tym zwłaszcza młodych wykształconych kobiet itp. Niski poziom kapitału ludzkiego i społecznego w rejonach odpływu migracyjnego powoduje trudności z rozwojem funkcji pozarolniczych, akceptacją innowacji technologicznych i społecznych (2016, s. 85).

We wcześniejszej analizie Rosner (2012) stwierdza, że na obszarach wiejskich 988 gmin (tj. 45,5\% z 2172 badanych) w okresie 2002-2008 liczba ludności w różnym stopniu zmniejszyła się. Aż 491 spośród nich (tj. 23\% w skali całego kraju oraz 49,6\% pośród gmin o zmniejszającej się liczbie ludności) charakteryzowało współwystępowanie dwóch cech: niskiego poziomu i słabej dynamiki rozwoju. To gminy problemowe, a ich przestrzenna lokalizacja zdaje się oczywista.

Gminy problemowe w większości skupione są w Polsce wschodniej i centralnej, na terenie byłego zaboru rosyjskiego. Największe ich skupiska są na pograniczu wschodnim, na południu sięgając dawnej granicy z Galicją oraz obszarach peryferyjnych Polski centralnej. Na pozostałych terenach pojawiają one głównie tam, gdzie występowały skupiska gospodarstw PGR-owskich, a więc w północnej części woj. warmińsko-mazurskiego i na Pomorzu Zachodnim (Rosner 2012, s. 107).

Te właśnie gminy, z którymi często sąsiadują takie o tylko niskim poziomie rozwoju albo tylko niskiej jego dynamice, powinny stanowić przedmiot rozważnego namysłu nad ich przyszłością oraz nowymi koncepcjami wspierania ich rozwoju. 
Takim obszarom powinna towarzyszyć szczególna, mająca inne założenia polityka wsparcia, oparta na „paradygmacie dopasowywania”, który „zakłada konieczność reagowania na «kurczenie się» obszarów wiejskich, poprzez dostosowanie do zmniejszającej się liczby ludności infrastruktury, usług publicznych i procesów inwestycyjnych" (Wilczyński 2016, s. 194), bo warto może powtórzyć za raportem Federalnego Urzędu Budownictwa i Gospodarki Przestrzennej RFN ${ }^{8}$, że „nie warto już żywić się nadzieją, że znane i wypróbowane koncepcje oraz instrumenty, a w szczególności działania promujące rozwój gospodarczy oraz wyznaczanie nowych terenów pod zabudowę, dadzą nowe impulsy do rozwoju gospodarczego i przełamią negatywny trend kurczenia się populacji” (za: Wilczyński 2017). Znamienne, że postulaty zmiany (nowego paradygmatu we wspieraniu obszarów wiejskich) płyną z tej części Europy, w której wypracowano - i z sukcesem wdrażano - program „odnowy wsi”. Zasady takiej polityki wypracowuje obecnie Austria ${ }^{9}$, niektóre niemieckie landy (np. Bawaria), mierzyło się z nimi województwo opolskie $^{10}$. Kluczową rolę odgrywa tu oczywiście diagnoza sytuacji, a więc: określenie, w którym miejscu spirali negatywnego rozwoju znajduje się dany obszar; czy utracił on już decydującą o rozwoju masę krytyczną, czy też posiada - dotąd może nierozpoznane - zasoby rozwojowe, mogące się ujawnić przez redefinicję jego funkcji. Polityka taka $\mathrm{z}$ jednej strony ogranicza marnotrawienie środków publicznych na nieprzydatne inwestycje, a $z$ drugiej może przeciwdziałać degradacji substancji materialnej wiosek i pozwolić lepiej zaspokoić potrzeby mieszkańców wsi, na przykład redefiniując sposób świadczenia usług publicznych. Dobrym przykładem mogłaby być konieczna redukcja sieci szkolnej, ale też pojawiania się systemów wsparcia nie tylko medycznego dla osób starszych, zwłaszcza w wyludniających się wsiach ${ }^{11}$. Obszary zwijające się mogą mieć różny zasięg: od kilku gmin, gminy pojedynczej albo tylko jej niektórych sołectw. Ta ostatnia sytuacja jest zresztą najczęstsza i sołectwa/miejscowości na ogół „zwijają się” żywiołowo, a proces ten traktowany jest jako „naturalny”. Rzadko występuje planowa polityka towarzyszenia tym procesom, gdyż wymaga ona zmiany sposobu myślenia o rozwoju obszarów wiejskich i dopuszczenia możliwości zanikania wsi. Jest to problem trudny do politycznego przeforsowania i późniejszej społecznej akceptacji. Wydaje się jednak jedynym wyjściem w sytuacji, gdy wszystkie inne rozwiązania, dotychczas

8 „Bundessamt für bauwesen und Raumornung” 2005 (za Wilczyński 2017).

9 Bo jak twierdzi propagatorka tej idei, Gerlind Weber, „Należy rozejrzeć się za politycznie możliwymi do przeforsowania sposobami aktywnego kształtowania i monitorowania procesów kurczenia się, aby doprowadzić do kontrolowanej «kuracji odchudzającej»” (za: Wilczyński 2017).

10 Szerzej na ten temat Wilczyński 2015.

11 Por. na ten temat „Model systemu opieki i wsparcia osób starszych w województwie opolskim”, https:// www.opole.uw.gov.pl/artykuly/1212/pliki/20140923105952_prace-nad-modelem.pdf [dostęp: 20.11.2017]. 
sprawiające wrażenie odpowiednich, zawodzą. Dopasowywanie - analogicznie do procesu rozwoju zrównoważonego - można nazwać procesem zrównoważonego zanikania wsi. Zarządzanie tym procesem, przy obecnym zupełnym braku instrumentów, jest znacznie trudniejsze niż zarządzanie rozwojem. I zapewne jako końcowy etap tego procesu pojawi się tytułowe zalesianie planowe ${ }^{12}$, ale zapobiegnie ono występującemu już zalesianiu (się) żywiołowemu.

\section{Bibliografia}

Adamski T., Gorlach K. (2007). Koncepcja rozwoju neoendogennego, czyli renesans znaczenia wiedzy lokalnej. W: Socjologia jako służba społeczna (s. 137-150). Kraków: Wydawnictwo Uniwersytetu Jagiellońskiego.

Babiński G. (1997). Pogranicze polsko-ukraińskie: etniczność, zróżnicowanie religijne, tożsamość. Kraków: Nomos.

Gorlach K. (2004). Socjologia obszarów wiejskich. Warszawa: Wydawnictwo Naukowe Scholar.

Grondona M. (2003). Kulturowa typologia rozwoju gospodarczego. W: L. Harrison, S. Huntington (red.). Kultura ma znaczenie (tłum. S. Dymczyk) (s. 101-115). Warszawa: Wydawnictwo Zysk i S-ka.

Grosse T.G. (2007). Innowacyjna gospodarka na peryferiach? Warszawa: Instytut Spraw Publicznych.

Grotowska-Leder J. (2005). Ekskluzja społeczna - aspekty teoretyczne i metodologiczne. W: J. Grotkowska-Leder, K. Faliszek (red.). Ekskluzja i inkluzja społeczna: diagnoza, uwarunkowania, kierunki działań (s. 25-44). Toruń: Wydawnictwo Edukacyjne Akapit.

Halamska M. (2005). Rozwój wiejski Portugalii w latach 1986-2000. Wzór czy przestroga dla Polski? Warszawa: Instytut Rozwoju Wsi i Rolnictwa PAN.

Halamska M. (2016). Struktura społeczna ludności wiejskiej na początku XXI wieku. W: M. Halamska, S. Michalska, R. Śpiewak. Studia nad strukturą społeczna wiejskiej Polski (s. 10-95). T. 1. Warszawa: Wydawnictwo Naukowe Scholar.

Halamska M., Stanny M., Hoffmann R. (2017). Studia nad struktura społeczna wiejskiej Polski. T. 2: Przestrzenne zróżnicowanie struktury społecznej. Warszawa: Wydawnictwo Naukowe Scholar.

Halamska M., Śpiewak R. (2008). Rozwój wiejski - nowa utopia czy konieczność? W: M. Drygas, A. Rosner (red.). Polska wieś w Unii Europejskiej. Dylematy i kierunki przemian (s. 493-416). Warszawa: Instytut Rozwoju wsi i Rolnitwa PAN.

12 Od czasu, gdy okazało się, że „nie każdy hektar musi rodzić”, z różnym nasileniem prowadzone jest zalesianie gruntów rolnych bardzo niskiej jakości. Informacje na ten temat znajdują się w statystyce masowej. Akcja ta wspierana jest przez WPR. W PROW 2014-2020 istnieje na przykład działanie „inwestycje w rozwój obszarów leśnych i poprawę żywotności lasów", na co przeznaczono ponad $300 \mathrm{mln}$ PLN. Oznacza to, że istnieją obszary, na których wdraża się ograniczenie funkcji rolniczych („zwija się rolnictwo”); dla pewnej grupy rodzin oznacza zmianę źródeł utrzymania (przez 12 lat dopłaty z tytułu utraty dochodów rolniczych) oraz charakteru pracy (pielęgnacja zalesienia przez 15 lat). 
Jałowiecki B., Kapralski S. (2011). Peryferie i pogranicza jako interdyscyplinarny obszar badawczy. W: B. Jałowiecki, S. Kapralski (red.). Peryferie i pogranicza. O potrzebie różnorodności (s. 2-32). Warszawa: Wydawnictwo Naukowe Scholar.

Jurcewicz A. (2003). Wspólna Polityka Rolna Unii Europejskiej. W: Prawo rolne (s. 57-79). Warszawa: Wydawnictwo Prawnicze LexisNexis.

Karwińska A. (2008). Gospodarka przestrzenna. Uwarunkowania społeczno-ekonomiczne. Warszawa: Wydawnictwo Naukowe PWN.

Knieć W. (2012). Wspólna Polityka Rolna a zrównoważony rozwój obszarów wiejskich w Polsce. Toruń: Wydawnictwo Naukowe Uniwersytetu Mikołaja Kopernika.

Koncepcja przestrzennego zagospodarowania kraju 2030 (2012). Warszawa: Ministerstwo Rozwoju Regionalnego.

Lacquemet G., Chevalier P. (2016). Capital territorial et développement des territoires locaux, enjeux théoriques et méthodogiques de la transposition d'un koncept de l'économie territoriale à l'analyse geographique. Annales de Géografie, 5, 490-518.

Mahler F. (1993). Marginalisation and maldevelopment. W: J. Danecki (red.). Insights into Maldevelopment. Reconsidering the File of Progress (s. 187-201). Warszawa: University of Warsaw, Elipsa.

Marini M., Mooney P. (2006). Rural economies. W: P. Cloke, T. Marsden, P. Mooney (red.). Handbook of Rural Studies (s. 91-103). London-Thousands Oak-New Delhi: Sage.

Marsden T., Murdoch J., Lowe P., Munton R., Flynn A. (1993). Constructing the Countryside. London: UCL Press.

Mendras H. (1976). Sociétés paysannes. Paris: Armand Colin.

Nowak A. (2012). Pojęcie, istota, przyczyny mechanizmy marginalizacji i wykluczenia społecznego. Chowanna, 1, 17-32.

Perrier-Cornet Ph. (2001). La problematique du développment rural en France: Une analyse critique. W: Agriculture et espace rural: quel développement? (s. 65-69) Varsovie: CFA.

Peyrache-Gadeau V., Pecqueur B. (2004). Les ressources patrimoniales: une modalité de valorisation par les milieux innovateurs de ressources spécifiques latentes ou existantes. W: R. Camagni, D. Maillat., A. Matteaccioli (red.). Ressources naturelles et culturelles, milieux et développement local (s. 71-89). Neuchâtel : Editions EDES.

Popławski T. (1995). Fałszywe tezy o polskim rolnictwie. W: J. Styk (red.). Stare i nowe struktury społeczne (s. 223-237). T. 2. Lublin: Uniwersytet Marii Curie-Skłodowskiej.

Proniewski M. (2014). Polityka rozwoju regionów peryferyjnych. Optimum. Studia Ekonomiczne, 6 (72), 80-90.

Rokkan S., Urwin D.W. (1983). Economy, Territory, Identity: Politics of West European Peripheries. Thousand Oak: Sage.

Rosner A. (2012). Zmiany rozkładu przestrzennego zaludnienia obszarów wiejskich. Warszawa: Instytut Rozwoju Wsi i Rolnictwa PAN.

Rosner A. (red.) (2000). Lokalne bariery rozwoju obszarów wiejskich. Warszawa: Unia Europejska - FAPA.

Rosner A., Stanny M. (2016). Monitoring rozwoju obszarów wiejskich. Etap II. Warszawa: Fundacja Europejski Fundusz Rozwoju Wsi Polskiej i Instytut Rozwoju Wsi i Rolnictwa PAN. 
Rykiel Z. (2011). Koncepcja pogranicza i peryferii w socjologii i geografii. W: B. Jałowiecki, S. Kapralski (red.). Peryferie i pogranicza. O potrzebie różnorodności (s. 55-64). Warszawa: Wydawnictwo Naukowe Scholar.

Silver H. (1994). Social exclusion and social solidarity: Tree paradigms. International Labour Review, 5-6, 531-578.

Szarfenberg R. (2008). Marginalizacja i wykluczenia społeczne - panorama językowo-teoretyczna. http://rszarf.ips.uw.edu.pl/pdf/miws_panorama.pdf [dostęp 4.03.2018].

Sztompka P. (2003). Socjologia. Analiza społeczeństwa. Kraków: Wydawnictwo Znak.

Van Huylenbroeck G., Durand G. (red.) (2003). Multifunctional Agriculture: A New Paradigm for European Agriculture and Rural Development. Aldershot: Ashgate Pub Co.

Weber G. (2009). Versuch einer praxisnahen Ordnung empfohlener Bodenschutzinstrumente, W: E. Hepperle, H. Lenk (red.). Land Development Strategies: Patterns, Risks and Responsibilities; Strategien der Raumentwicklung: Strukturen, Risiken und Verantwortung (s. 143-156). Zürich: vdf Hochschulverlag ETH Zürich.

Wilczyński (2015). Jak bronić wieś przed depopulacją i zanikiem. Problemy Planistyczne, wiosna, 7-29.

Wilczyński R. (2016). Sytuacja rozwojowa wsi w woj. opolskim w warunkach depopulacji. Studia Obszarów Wiejskich, 41, 193-211.

Wilczyński R. (2017). Odnowa wsi a paradygmat dopasowania - czyli co robić, gdy wsie zanikają. Referat na XXXIII Seminarium Geografii wsi, Kraków, 1-2.06.2017.

Wilkin J. (2010). Wielofunkcyjność rolnictwa - nowe ujęcie roli rolnictwa w gospodarce i społeczeństwie. W: J. Wilkin (red.). Wielofunkcyjność rolnictwa. Kierunki badań, podstawy metodologiczne i implikacje praktyczne (s. 17-40). Warszawa: Instytut Rozwoju Wsi i Rolnictwa PAN.

Woś A. (2004). W poszukiwaniu modelu rozwoju rolnictwa polskiego. Warszawa: Instytut Ekonomiki Rolnictwa i Gospodarki Żywnościowej.

Woś A., Zegar J. (2002). Rolnictwo społecznie zrównoważone. Warszawa: Instytut Ekonomiki Rolnictwa i Gospodarki Żywnościowej - PIB.

Zarycki T. (2000). O niektórych dylematach współczesnych badań nad przestrzenią społeczną. Studia Regionalne i Lokalne, 4 (4), 5-22.

Zarycki T. (2010). Peryferie. Nowe ujęcia zależności centro-pryferyjnych. Warszawa: Wydawnictwo Naukowe Scholar.

Zarycki T. (2011). Peryferie czy pogranicza? Krytyczne spojrzenie na współczesne sposoby posługiwania się pojęciem „pogranicza”. W: B. Jałowiecki, S. Kapralski (red.). Peryferie i pogranicza. O potrzebie różnorodności (s. 33- 54). Warszawa: Wydawnictwo Naukowe Scholar. 


\title{
Supporting or Afforesting? Dilemmas in the Development of Rural Problem Areas in Poland
}

\begin{abstract}
Approximately one third of rural areas in Poland have been described as problem areas by planners. They represent mostly peripheral or marginalised areas, characterised by several deficits (of physical, human, social, and cultural capital), that cannot develop without external help. Moreover, formulating the aims of development is even more problematic. Challenges raised by the new paradigm of sustainable rural development which refers to numerous elements of the sociological idea of neo-endogenous development are especially important. The present analysis of deficits of the problem areas underscores the significance of human, social, and cultural deficits. Such is the context of external support for these areas and the limits of social rationality thereof. The idea of negative spiral of development and the matching paradigm - a new development paradigm for some of the discussed areas both proposed by Gerlind Weber - are of use in explaining the described phenomena.
\end{abstract}

Keywords: problem areas, capital deficits, spiral of negative development, matching paradigm. 